\title{
Civilisations
}

Revue internationale d'anthropologie et de sciences

humaines

58-2 | 2009

Intimités et inimitiés du religieux et du politique en

Afrique

\section{Ambiguous Secularism}

Islam, Laïcité and the State in Niger

Abdoulaye Sounaye

\section{(2) OpenEdition}

\section{Journals}

Édition électronique

URL : http://journals.openedition.org/civilisations/2025

DOI : $10.4000 /$ civilisations. 2025

ISSN : 2032-0442

Éditeur

Institut de sociologie de l'Université Libre de Bruxelles

Édition imprimée

Date de publication : 30 décembre 2009

Pagination : 41-58

ISBN : 2-87263-027-9

ISSN : 0009-8140

Référence électronique

Abdoulaye Sounaye, «Ambiguous Secularism », Civilisations [En ligne], 58-2 | 2009, mis en ligne le 30 décembre 2012, consulté le 19 avril 2019. URL : http://journals.openedition.org/civilisations/2025 DOI : 10.4000/civilisations.2025 


\title{
Ambiguous Secularism \\ Islam, Laïcité and the State in Niger
}

\author{
Abdoulaye SounAYE
}

Résumé : Au début des années 1990, la démocratisation a correspondu au Niger à une réforme politique rompant avec les régimes militaires, mais tenant aussi à l'écart les influences religieuses. L'adoption du principe de la laïcité visait d'abord à établir l'autonomie de la sphère politique par rapport à la sphère religieuse, et deuxièmement, la soumission de l'autorité religieuse à l'autorité politique. La consécration de ce principe amené à la critique d'acteurs musulmans qui ont fait valoir qu'un tel principe violait l'identité religieuse de la société nigérienne. Ce papier discute de la difficulté qu'il y a à séparer les réalités politique et religieuse, dans la mesure où des organisations islamiques ont désormais pris pied dans l'arène politique, professant divers discours inspirés par la religion et cherchant à convertir la politique nigérienne à l'islam. Aujourd'hui, cet activisme a mené au réarrangement de la position de l'État vis-à-vis de la religiosité et de son rôle public. Ce cas de sécularisme ambigu peut mener non seulement à une réinterprétation du sécularisme, mais aussi des processus de démocratisation eux-mêmes.

Mots-clés : démocratisation, laïcité, Islam, identité religieuse, sécularisme.

Abstract: In the early 1990s, democratization in Niger meant a political reform detached from the military rule, but also safe from religious influence. The adoption of the principle of a radical secularism (laïcité) sought, first, the autonomy of the political sphere from the religious one, and second, the submission of religious authority to the political one. The consecration of this principle led to the criticism of Muslim public actors who argued that such a principle was violating the religious identity of Niger's society. This paper discusses the difficulty to separate the realm of politics from that of religion as Islamic organizations and Muslim actors have stepped into the political arena, articulating various religion-inspired discourses and seeking the conversion of Niger's politics to Islam. Nowadays, this activism led to a rearrangement of the state's position in relation to religiosity and its role in the public domain. This case of ambiguous secularism, I suggest, might be one of a reinterpretation not only of secularism, but of democratization itself.

Keywords: democratization, laïcité, Islam, religious identity, secularism. 


\section{Introduction}

$\mathrm{T}$

he democratization process that began in 1991 in Niger set the ground for a sociopolitical activism that led to the emergence of many civil society organizations. Among these, Islamic associations proved to be a dynamic force in the struggle to reshape the norms of public life. At the early stage of their development, these organizations were primarily concerned with social policies they saw detrimental to the religious identity of Niger. Protest defined this initial phase of Islam's expression in the democratization era. Since then, Islam's presence in the public sphere has taken another direction as Muslims' religious entrepreneurship focuses on more concrete social transformation initiatives.

Introducing a sample of discourses and initiatives, this article highlights the grievances of Muslim actors who are accused of "intrusion" in the political sphere, and the difficulty to submit Islamic actors to state and political authorities. This occurs in a context where Muslim actors attempt to islamize public life despite a French inspired constitutional framework that consecrates the regime of laïcité, what I call here radical secularism. A structural effect ensued, complicating modes of doing politics as well as the relationship between the religious and the political spheres. Within this context, the examination of secularism cannot overlook the evolution from a radical secularist frame - symbolized by laïcité - to a soft secularism within which political actors as well as state institutions are seeking to capitalize on religiosity. This recognition of religiosity within the state institutions, contrasts markedly with the strong reprobation of religion that laïcité features. I will argue that this change is only the indication that Islam has never vacated the domain of the state and politics, despite the early democratization assumptions and effort to establish a post-religious governance. Thus, Niger has never achieved a fully enforced regime of laïcité because of the sociopolitical significance of Islam, but also because of the need among state officials and politicians to legitimize their authority in particular in the wake of Muslims' concern about strict secular governance that would marginalize their religious identity. Social and political activism of Muslim groups led to a reevaluation of a strict separation between religion or religiosity and politics, and to what might be called an ambiguous secularism.

As Asad (2003) notes, secularism has no single origin. Therefore, if the case in Niger, as I contend, is no longer about religion and politics in general, but about the state and Islam, it still concerns the modality of the interaction between the religious and the temporal authorities. It still speaks for the struggle among African societies to define the guiding principles of their public lives within which the modern state is now central, if not the key institution. Therefore, if secularism in general cannot be understood without reference to religion which gives it its meaning, in the case of laïcité, the practice tells more about the state than religion per se. Laïcité evokes and translates the personality of the state and the uncertainties of the public sphere (Casanova 2006). Furthermore, as the last section of this article shows, and following Calhoun, "one could argue that a sharp division between secular and religious beliefs is available only to the secular" (Calhoun 2008). Because of this imbalance, one of my propositions is that to fully grasp the significance of Niger's recent experiences of secularism, we need to look at how ulama (Muslim clerics) have reacted to the secularization process and at the objections they leveled against the sociopolitical transformation democratization has brought. Put another way, to better understand the problematic nature of laïcité in contemporary Niger, we need to look at the way Muslim 
clerics have perceived this shift toward a separation that no longer provides them with a sociopolitical status they had certainly enjoyed.

From this perspective, secularism appears to be at first a religious issue. However, even though Niger comprises other traditions, notably indigenous religions and Christianity, only Muslims have expressed concern about laïcité, perhaps because most Muslim representations of laïcité have tied it with Frenchness. Laïcité and the separation between state institutions and religion it implies are also perceived within Muslim circles (interviews: Umar 2004; Mai Zabura 2004) as the postulates of an ideological order based on a Christian religiosity that has conceded defeat to Western rationalism.

In its implementation in Niger, laïcité was essentially a Muslim issue. It was about the status of Islam, the religion of the majority of Nigeriens, and its role within the public sphere. Early on, the assumptions about the democratic reform were rather influenced by the notion of a post-religious state in which governance would emancipate itself from Islamist determination. The fear of a growing Islamic intégrisme, the French concept that captures the anxieties about Islam and religious fundamentalism, was pervasive among political leaders and secularists who at the time dominated the civil society (Garba 1991). This fear of intégrisme led the framers of the 1992 constitution to set constitutional boundaries designed to limit and control the influence of political Islam. Religion - meaning principally Islam - was then disqualified from political appropriation. At that time the growing influence of political Islam in Algeria and Northern Nigeria served as a pretext for a sharp separation requiring the subordination of religious authority to the temporal one.

Recent contributions to the examination of secularism in the modern world have pointed to the limits of the separation model (Hurd 2008; An Na'im 2008; Hashemi 2009). Hurd argues that in international politics, religion has often been central to positions and decisions. As far as Islam is concerned, she points to the fact that one can understand political Islam only outside of the Western construction of the secular. In rejecting the assumption that Islam and liberal democracy are incompatible, Hashemi (2009) contends that Islam, liberal democracy and secularism can perfectly foster a viable political order. While An Na'im and Hashemi agree on the benefit of democratic politics in Muslim contexts, they seem to disagree on the role of the state. In practice, as the literature has emphasized, Muslims have responded to secularism in various ways. Violence, nationalism and public piety have been among these responses.

What is interesting for my discussion is not that the secular is a Western construction, but that it is a construction at all, i.e. a result of a historical process that owes to the state and the secularists, on one hand; and on the other hand to Muslim public actors. In the case of Niger's public sphere, it is precisely the double construction of laicite that makes the issue of secularism an interesting point of departure to examine how representations of moral order (Alidou and Alidou 2008; Sounaye 2007; Masquelier 1999; Villalon 1996) compete within a democratization context. Recent research on Islam in Niger seems to concur on the fact that the current Islamic activism has invigorated the public arena (Alidou 2005; Idrissa 2005; Souley 2005; Sounaye 2005). In general, even though democratization has boosted religious studies in Niger - with Islam now a major pole of social science research - scant have been the studies on laïcité (Idrissa 2005; Sounaye 2009a and 2005). This article is a contribution to the examination of the fortunes of secularism in contemporary Niger. 
Preliminary research for this article was conducted in 2003 and 2004 at the beginning of Tandja's first term when his regime consistently rebuked attempts to build on Islam for political gains. I was able to conduct more research in the summer of 2008 for additional interviews and conversations in Niamey, Maradi and Zinder. Cassettes-sermons and radio interviews were also collected from ulama and radio stations broadcasting in Niamey. My broad interest in the genealogy of Islamic activism in Niger led me to spent numerous weeks in Niamey for archival research and attendance to sermons. The voices I will introduce in what follows may not be the most famous and representative of all Islamic sensibilities in the country, but they exemplify some of the feelings, perceptions and representations Muslims have expressed in relation to a laicization process and its ideological basis. I have already examined some of the ways in which the state and the Secularists have represented the secular order (Sounaye 2005 and 2007). In what follows, I turn to the representations of Islam's "representatives."

\section{Background and Context}

Political activists and other supporters of democratization in various contexts have argued that democratic politics are only achieved and legitimized when governance reflects the deliberations and the will of the people (cf. Monga 1995). From this perspective, sovereignty and self-determination became key notions in defining and conceiving political participation at the end of the 1980s and early 1990s. Simultaneously, as a consequence of a global framework that saw the collapse of the Berlin Wall, the end of the rivalry between Communist and Western democracies, and the emergence of a "natively triumphalist Occidentalism," Western assistance for developing democracy focused primarily on the empowerment of civil society (Hefner 2000; Carothers and Ottaway 2000: 6).

In African contexts, the push for democratization had an enduring effect on popular modes of expression, but also on social and political imaginaries. Niger was no exception as the effect of the political reform proved to be sweeping, in particular because all political spaces had been, especially during Kountché's regime (1974-1987), under strict state control and dominated by the statist idea that the state mediates development (Potter 1997). In retrospect, analysts may ask whether democratization gained support because of its promise of social justice and freedom, or because of the contempt in which most of people held the then authoritarian regimes in Africa. For whichever reason, liberal democracy became for both the state and civil society the ideological framework.

Before the democratization process, two military regimes dominated the political history of Niger. The first was the regime of Seyni Kountché (1974-1987) which, like all military regimes, was wary of any contestation and opposition to its power. Naturally, it permitted very limited participation of civil society. Freedom of speech and association were largely denied and in fact, most authorized associations were state-sponsored. As an illustration the only Islamic organization in the religious sphere was the Association Islamique $d u$ Niger (AIN), a body of religious clerics whose main mandate was to help control and regulate the religious sphere by preventing organized Islamic dissent.

After Kountché's death, Ali Saibou (1987-1991) succeeded him and maintained the status quo, even though he introduced a "décrispation", that is a political détente, in an attempt to distance himself from the image of the harsh ruler his predecessor had carried. The move was aimed at gaining him popular support and legitimacy in the political arena 
where he was viewed as apolitical virgin, but also in the military where several officers were eyeing to succeed Kountché. It was under his rule that the mobilization for political reform culminated in a National Conference which set the stage for a new constitution and free elections. Under both local and international pressure, he had to comply with the global trend toward opening up the public sphere and political pluralism. At that time the emerging local civil society comprised mainly the students' organization USN (Union des Scolaires Nigériens), the federation of trade unions USTN (Union des Syndicats des Travailleurs $d u$ Niger), women's organizations such as RDFN (Rassemblement Démocratique des Femmes $d u$ Niger), and human rights organizations such as ANDDH (Association Nigérienne pour la Defense des Droits de l'Homme). Indeed, these organizations gained so much power that they were literally able to impose to Saibou major decisions affecting not only his own future as head of the state, but also the social, political and economic life of the country. As far as the Islamic sphere is concerned, Saibou espoused a continuity policy, maintaining the quasistate institution status of AIN. Muslim clerics under both Saibou's and Kountché's regimes enjoyed monopoly in the Islamic sphere as AIN was granted public office and guaranteed public funding for all its activities.

The divorce between Islam and the state occurred with the democratization era when AIN lost its monopoly over the Islamic sphere, as democratization led to freedom of association, and to a multiplication of Islamic organizations. Concomitantly, the laïcité principle aimed at making religion a non-political factor. But this divorce between the state and AIN only lasted during the regime of Mahamane Ousmane (1993-1996), the first elected regime of the post-military rule. Actually, Bare's pseudo-democratic rule (1996-1999) arrived to power after a coup and a contested election that propelled him to the Presidency. In dear search for legitimacy resorted to Muslim clerics in the hope they will guarantee him the support of their followers (Sounaye 2007). Under Tandja (2000-present), another return to laïcité occurred, at least until his regime consecrated the Qur'anic oath as a public ritual in many state institutions. These up-and-downs suggest that in Niger, relations between state and Islam heavily depended on the mode of governance, but also on the individual political agenda and calculations of the officials in place (Sounaye 2007 and 2005).

In general, the structural impact of the liberalization trend was limited to neither the political sphere nor the secular civil society. It affected also the Islamic sphere since the core Islamic organizations were created in the same context. The actual problem, according to these organizations was how the secular state became a sacred institution with the right to have the last word, whereas the Qur'an and the Sunna, should define the sociopolitical framework in a true Muslim society. Ulama (Muslim clerics) reactions culminated in the Manifeste pour la Réhabilitation de l'Islam au Niger, a joint declaration that the main Islamic organizations of the country, namely ARCI (Association pour le Rayonnement de la Culture Islamique), ANASI (Association Nigérienne pour l'Appel et la Solidarité Islamique), AIN (Association Islamique du Niger) and ANAUSI (Association Nigérienne pour l'Appel, l'Unité et la Solidarité Islamique), made public prior to the 1992 constitutional referendum and general elections. In substance, they demanded that authorities such as the President of the Republic, the President of the Parliament, the President of the Supreme Court, and the Prime Minister, all be Muslims.

If anything, this demand reveals on the one hand, the failure of Islamic organizations to stop what they see as a destructive structural secularism, and on the other hand, a gradual 
re-adjustment Muslims' fight against the pervasive ethics of laïcité. As long as civil society organizations and political parties - the central forces of the public space at the time - attributed a foundational role to laïcité, Islamic organizations realized that they would find no support in their attempt to make Islam the foundation of governance in Niger. But their move to target specific authorities, rather than the structure in itself, still aimed at counteracting the constitutional separation between state and religion. In their view, despite the structural context of laïcité, the religious identity of state authorities could guarantee or at least favor the practical conformity of political decisions with Islam. The assumption was that they would favor Islamic principles. I must note that opting for agency rather than principles has proven to be a tactic in an overall strategy to influence Niger's political ethics, as controversies over state initiatives related to social policies have shown; in particular with the cases of the Family Code Project that was rejected by most Islamic organizations, and the 1999 ratification of the United Nations Convention on the Elimination of all Forms of Discrimination Against Women harshly criticized by Islamic organizations to the point that the government was forced to append reservations to several of its articles (Sounaye 2005).

As far as the sociology of the Islamic sphere is concerned, within the context of democratization, Izala, an Islamic reform movement, which has been the object of many studies in West Africa and Niger (Loimeier 1997; Masquelier 1999; Maikorema 2007; Sounaye 2009b), was not the only player. Its agents were the most visible because of their discourse of rupture as they add to their puritanic understanding of Islam a social critique dimension. Other religious and Muslim actors also seized the liberalization as an opportunity for Islamic revival. Among the most active in this group are many young Muslims trained both in Niger and in foreign countries including Nigeria, Sudan and Saudi Arabia. Other participants in this movement include former Marxist students who were trained at Abdou Moumouni University, the main higher educational institution of the country. Marxism becoming an outdated and even defeated ideology, they embraced Islam with already tested rhetorical skills and social engineering techniques. While secularists were fighting for democratization and human rights, the mantra of these fresh Muslims was reislamization.

The secularists I evoke in this article are generally trained in the western-oriented educational system. Forming the core of this system, they represent the base of the political elite. They are Muslim in majority, but rarely see religion as the prime drive of their lives and the lenses through which to interpret their acts, thoughts and commitments. Intégristes (the French concept for radical Islamists) criticize them for their insufficient religiosity, westernized minds and being too subdued.

Generally speaking, the concern about the status of religion in the public sphere is not exclusive to Muslims portrayed as Islamists, fundamentalists, radicals or intégristes (Alidou and Alidou 2008; Souley 2005). If the latter are the most vocal in the public sphere, other Muslims have also joined them in their call for an Islamic moral order, although with less publicity and zeal. These moderate sensibilities may not demand that Islamic rules and principles regulate all domains of public life, but they still see the benefit of Islamic laws in domains such as inheritance and marriage.

In Niger, in recent years, many groups have emerged invoking Islam as their raison d'être. Their emergence has led to a new culture of Islam that seeks to transform social habits, cultural norms and more generally public ethic. This move to cast religion essentially 
as an ethical domain has further complicated the dynamics of the religious sphere, with the diversification of the voices speaking for Islam.

\title{
Voicing Concerns about laïcité and democratization
}

In May 2009, in a move to remain in power after the two terms limit that the constitution authorizes, President Tandja made public his bid to hold a referendum on a new "constitution more in tune with Niger's sociopolitical reality." This prompted a multitude of reactions in the public sphere, including from religious leaders. Muslims' public pronouncement on the issue was unexpected because religious authorities have rarely taken side in a context of political crisis of this magnitude. Usually, because of their authority and social capital, they mediate between the protagonists, seeking a peaceful resolution of the issues while they carefully avoid any gesture that might be interpreted as supportive of either side. AIN's call to calm during the crisis illustrates this pattern of behavior.

But in the present case, Halidu Yahaya of CASIN (Collectif des Associations Islamiques $d u$ Niger), a group that comprises 34 Islamic organizations found the occasion appropriate to reintroduce the debate over the religious identity of the state. Arguing that it is unreasonable to maintain secularism in its current form in Niger, he reiterated the old claims that Islam has been "victimized" in the process that led to the institutionalization of laïcité. However, despite his criticism of constitutionalism in general, the drafting of a new constitution as expressed through Tandja's project represents, according to this Muslim cleric, an opportunity to make up for the failure to recognize Islam within the constitutional frame. The opportunistic attitude he voices seeks not only a rearrangement, but most importantly a remedy to the "exclusion of Islam":

\begin{abstract}
We oppose both the current and the planned constitutions. Nothing is more important to Niger than Adini [the religion of Islam] .... The separation of religion from government is a very dangerous principle for a country like Niger. We support the project of a new constitution... We will not support the prohibition of religion from public affairs neither the exclusion of ulama from having any say; that is a situation we will not accept...we oppose this constitutional principle...it is inacceptable to decree the state cannot build mosques. That's a peril [to our identity]. (interview: Yahaya 2009)
\end{abstract}

This statement raises the issue of the legitimacy of the state in its current ideological form: How could one legitimize politics and governance in Niger when Islam and its "professionals" are kept away. The exclusion of ulama (Muslim clerics) from the political arena worries Muslim leaders, especially those who have enjoyed the status of a quasi state institution until the beginning of the democratization process (Sounaye 2009a). In this case, the rhetoric of justification of they belonging to the political domain has often resorted to a theology of decay arguing that since politics have been left in the hands of unreligious leaders, public affairs have suffered corruption. Injustice, immorality and inefficiency are said to be the malediction democratization and its secular principles have brought. In such discourses, Islam's ethical dimension is considered as the reservoir of norms and values that should inspire political action and ultimately state ideological foundations. Because these norms and values are viewed both as the foundation and the regulatory principle of Muslim sociopolitical life, their lack in secularist governance leads to unjust rule. For Muslim critics of secularism like Yahaya, governance that hands over its guiding principles turns into unlawful rule and ultimately faces decomposition. 
Similar to other reactions I have analyzed (Sounaye 2005 and 2009a) the anti-secularism that Yahaya's position echoes grew out of an opposition to the state's un-religious principles, and the unwillingness of political authorities to submit public service to religious determination. But, as I show in the next section, Yahaya is not alone. His position is only the latest to reach the public space.

\section{Mai Zabura: a Muslim critic of the state and democratization}

Mallam Mai Zabura is a 70+ old alem (Muslim cleric) who established himself as an authoritative Islamic figure in Maradi, the capital of the central region of the country. Like many ulama (Muslim clerics) of his generation, he is known for lending a fervent support to Kountché's regime. More than twenty years after this military regime, he still criticizes the lack of imagination, deficient wisdom and maturity that characterize in his perspective the post-Kountché's era. As he repeatedly states, "we have wasted the legacy of Kountché." During both series of interviews (2004 and 2008) I had with him in Maradi, he has consistently tried to convince me of this feature of democratization. His membership in AIN (Association Islamique du Niger) has earned him respect in the Maradi region, but most importantly, it has allowed him to build a network of relations among state officials and traders, the key agents of the region's economy. In this position he founded one of the nation's most notorious and influential Makarantu (Quranic schools). His success is manifested through the numerous disciples who have followed his steps in establishing themselves as learned men with their own Makarantu. Others have become successful traders in Maradi, but also across the border in Nigeria. In recognition, they often support him with goods, but also financial contributions in particular for his regular trips to Mecca for the Hadj (Muslim pilgrimage in Saudi Arabia). Still another group of his trainees, perhaps those he is the least pride of, have embraced Izala, a movement of reformist discourses that have challenged his authority at various occasions. In Maradi, one of the memorable verbal altercations between the Izala reform movement and the Sufi brotherhoods features himself and one of his trainees. For this reason, discussing the current changes in the Islamic sphere is usually an emotional matter for this cleric.

Unlike many ulama of his generation, who sought higher religious education in Nigeria, the Arab countries, or elsewhere in West Africa, Mallam Mai Zabura spent his youth and part of his adulthood traveling in the Maradi region, searching for knowledge, following whoever is reputed for Islamic learning, enduring the harshness and the abnegation of such enterprise. When he finally settled in Maradi, he was already a well-respected young Mallami (learned man, in Hausa) increasingly consulted. His confirmation as a religious public figure came as no surprise during the military regime and the institutionalization of AIN in 1974 when he was co-opted as one of the representatives of the Maradi region within this organization. Committed to the organization, he would become one of its key members, in part because of his communication skills. Alert and eloquent, with a striking mastery of Hausa rhetoric, Mallam Mai Zabura attracts large crowds to his public sermons in Maradi and beyond. In Niamey, he is often the guest of groups and organizations who invite him to deliver sermons, especially during the month of Ramadan.

My conversations with him have always ended up as an occasion for him to raise the issue of laïcité and the fragmentation of the Islamic sphere because of the multiplication of Islamic associations. For him, both phenomena contribute to a "major setback" for Islam and social cohesion in Niger. He stresses the discord (fitna) that characterizes now relationships 
between Muslims since the liberalization of public discourse, the freedom of speech and organization and the subsequent emergence of young Muslim actors who do not hesitate to challenge the authority of the establishment. His favorite illustration of such phenomenon is that "today, many Muslims use sermons as a platform to attack other Muslims."(interview: Mai Zabura 2004) He blames secularism for this, since "what happened with the separation of Hukuma [state] from Adini [religion] is that people have now the right to do anything they want; no one can forbid anything; hence the increasing fitna." (interview: Mai Zabura 2004) Obviously, this position reflects his personal history, with some of his former pupils now overtly disavowing him. It represents also a reaction to the fragmentation of the Islamic sphere and the confrontational atmosphere resulting from the Reformers' attempts to break through with subversive anti-brotherhood discourse (Sounaye 2009b; Maikorema 2007; Umar 1993). This happened, according to him, because democratization has opened a Pandora box by depriving ulama of their statutory role and authority. Democratization's "rejection of religion" is to blame precisely because this has given way to siasa (politics, from Arabic), a political practice that challenges both the political authority of the state and the moral authority of ulama. Additionally, for this Muslim cleric, siasa takes another meaning: it represents the new political scheme that has provided little for the stability of the country and social justice. Instead, siasa, for Mallam Mai Zabura, proved to be the worst of all politics as it has institutionalized mal-governance.

Generally speaking, Mai Zabura's views on the state's institutional secularism stress the fact that despite the multiplication of Islamic learning institutions, the growing number of learned young Muslims, and the increasing interest among Muslims to see their public life being shaped along Islamic principles, the state continues to reject Islam as a valid normative source of its policies. The separation between religion and state has done no good, instead "laïcité came to pervert morals, because in separating hukuma and adini, it cut Islam from the support of political authorities. Central to his view is that "Adini [religion] without the support of Hukuma [political authorities] has no power;" at the same time, a mode of governance that "does not show respect and consideration to Islam lacks legitimacy." He acknowledges that Niger has had a particular sociopolitical trajectory which makes it unrealistic to impose full Shari'a (Islamic law). For this reason, he does not demand that Niger becomes an Islamic state, but only that state institutions give Islam its due role. His suggestion of collaboration between the two forms of authority is grounded in the perception of a mutual need between the two institutions: while religion alone has no sufficient power and authority to maintain order, the state as a sociopolitical institution would lose most of its legitimacy if it neglects its subjects' religious identity. Reiterating a position he has repeatedly expressed in his sermons, Mallam Mai Zabura claims that in Niger, where Muslim clerics have always had a significant influence over modes of governance, political authorities must consult with those who bear religious authority. This (lacking) necessary collaboration is obviously for Mallam Mai Zabura the missing link in current democratic politics, and the main reason of his grievance.

This characterization of democratization and Islam is not exclusive to Mallam Mai Zabura. Many critics concur with him. First, they are convinced that Muslim clerics are the vigor of Islam; and second, governance has become a political mode that provides public services only to selected people, mainly state officials, politicians, their friends and family members. On that ground, Mallam Mai Zabura was prompt to justify the military coups of January 1996 and April 1999 that many supporters of democratic politics have viewed 
as major setbacks. For him, these events are only the consequences of a political project foreign to Niger's identity. Returning to his admiration of Kountché's military regime, he even suggests that these coups be viewed as attempts to put back on track a too liberalized reform running astray. Therefore, the failure of democratization - a conclusion he reached -, lies in the distance the liberalization process has taken from the religious actors, but also in the contempt in which this political process has held religious authority.

As we can see, one of the issues the democratization process has brought to the forefront of public debate in Niger is the religious identity of the country and how state institutions should translate this identity within their lives. Many assumptions have been laid out in this debate, but the most striking relates to the way ulama represent their role in terms of the defense of Niger's religious identity. It is manifest that the objection to laïcité has become central to this defense. In fact, from a broader perspective, it is fair to say that Mai Zabura and Yahaya are only two voices among many who are concerned with an alternative to laïcité. The current entrepreneurship that characterizes the Islamic sphere testifies to the generalization of de-laicization practices.

\section{Islamic Entrepreneurship and the de-secularization of the society}

Beyond discourse, constructing Niger's identity in a move to counter laïcité took diverse forms. Thus, besides the most prominent faces of organized Islam in Niger, namely the Islamic associations, many small and informal groups (learning and literacy groups, youth clubs, women groups, etc...) have emerged to carry on the popularization of the Sunna, the tradition of the Prophet Muhammad. Ideological concerns do not disappear however; they only lose primacy as a preoccupation. Sociologically, these initiatives have taken two main forms: learning and preaching communities. Each has contributed to the structural transformation of the Islamic sphere, but also to the redefinition of the contours of civil society, a space that has not included Islamic organizations until recently. Obviously, these communities are not exclusive social formations as participating in preaching is perceived as another form of learning. In fact, it is very common for people to be part of both kinds of communities, since one space is viewed as the continuation of the other. I will argue that in Niger, these communities have become the embodiment of the pervasive Islamic antisecularist discourse. In this section, I briefly discuss the cases of Abubakr Guero and Maiga, two religious entrepreneurs who illustrate the kind of discourse and practice that seek to have a direct social impact on Islam in Niger.

Abubakr Guero is a prominent reformist preacher known in both Niger and Nigeria. His cassette-sermons rank among the most circulated in Niger. He usually uses the notion of Taimakon Adini (lit. serving religion, from Hausa), to conceptualize the imperative for Muslims, regardless their social status, to contribute to the popularization of the Sunna (tradition of the Prophet Muhammad). Thus, each occasion of sermon is for him an opportunity to communicate the message of the Prophet. Performing sermon implies reading the prophetic message for each and every generation. But, most importantly, it supposes what may be called the generational reappropriation of the Qur'an, not for the simple reason of correcting previous interpretations, but first and foremost in order to situate and then assume one's own religious obligation. Not surprisingly, youth becomes the main target of Guero's sermons. 
In his most popular cassette-sermon to date (Guero 2004), he calls on young people (yan zamani), in particular the university students and the Muslim elite, the main workforce of the state administration, for whom he set the priority to remedy to the "lack of Islamic principles in the state system." In the process of remodeling the ideological basis of the administration and the political arena as a whole, Muslim youth and elite should be at the forefront. Muslims should engage in the public sphere in a proactive way, rather than isolate themselves and concede to their marginalization and exclusion. Unlike Mai Zabura who sets no specific agenda, Guero has increasingly been laying out the steps and the categories of actors that should lead the reislamization of Niger's society. For him, consolidating the ideological role of Islam must be the priority of Muslims in Niger. Hence, in this democratization era, he urges Muslims to affiliate with political parties and be visible in civil society formations. For, it is only through the assertive presence of students and bureaucrats that governance and public order in general, could be corrected and aligned along Islamic principles. Additionally, in order to sustain this policy and reestablish the primacy of Islamic values in public affairs, he suggests an aggressive religious education within the family. Being the basis of the community, the family provides better conditions to raise religious children. In fact, he sees the family as the first moral space within which religiosity should be cultivated and transmitted. Relentlessly, he has crisscrossed villages and urban areas to "awaken" Muslims to their duties.

Along with preaching, other practices have become also the domain of Muslim entrepreneurship in Niger. For example, learning has become a primary area where individual Muslims as well as groups have attempted to materialize their initiatives. Within the last decade, learning proved to be among the most dynamic sectors where Muslims have invested their imagination to carry on the reislamization agenda in Niger. To illustrate this spirit of entrepreneurship, one needs only look at how the learning groups and centers that ANASI (Association Nigérienne pour l'Appel et la Solidarité Islamique) has implanted, have reconfigured the geography, but also the sociology of Islamic learning in Niger.

Adamou Maiga, a long time leader of this organization repeatedly stressed the significance of learning in consolidating the Islamic faith in Niger: "to be good Muslims, people need to know their religion."'(interview: Maiga 2008) His case is an interesting one. Like Mai Zabura, he was trained exclusively in Niger with ulama he has followed since his young age. $\mathrm{He}$ played a key role in building the communities of learning that ANASI has developed across Niamey in the last fifteen years. He describes his effort since 1991 in terms of consolidating the Islamic base of Niger's culture. His focus on teaching an elite female constituency speaks for the centrality of women in his vision of the "new Islamic society." Because women are the maintaining force of the family structure, a program of islamization, according to Maiga, should necessarily take into consideration their pivotal role for, "if they learn Islam, it will trickle down onto their offspring" (interview: Maiga 2008)

Maiga's position is in line with ANASI's overall approach to Islam in the public sphere. In effect, as an elite themselves, the founders of ANASI were initially inspired by both the idea of an Islamic dominion as materialized with the Sokoto caliphate, and the political model of the Algerian FIS (Front Islamique du Salut). In the early stage of its inception, the group that would later become ANASI and articulate its political vision was rather thought as revolutionary in the Nigerien context. As Maiga pointed out, 
When political parties were being authorized, just before the National Conference, our first meetings were about how to create an Islamic party. Our initial intention was to found a political party, but we realized it will never be legalized because of "laïcité," and it was going to be prohibited anyway; so we settled on an Islamic association. That's how ANASI was born. (interview: Maiga 2008)

It is a common preoccupation among Islamic organizations to provide religious learning to Nigeriens, especially those who have been exclusively trained in the state secular school system. The "Yan Lakkol" (the Schooled, from Hausa) or "Intellectuals", as this social category is called, are portrayed as lacking the knowledge of Islam, but also as an obstacle to Islam if they are not provided the light of adini (religion). The reason Islamic organizations advance include the elite status of this social category and their influence in the everyday life of the state. Therefore, in order to overcome this obstacle, early on, ANASI chose to focus on "enlightening" the "Intellectuals," creating various fora for "training" in Islamic culture and values. The strategy has consisted mainly in using the language and the media of this category of targeted people. French became the primary language of ANASI's TV, radio and open air sermons. In addition, in Niamey for example, Islamic pamphlets and booklets became highly circulated religious commodities while more bookstores were established in the markets of the main cities and gathering places. Consequently, ANASI membership grew considerably among civil servants and high school and university students. Maiga has played a significant role in this, not only in training many groups of these social categories, but also through the series of pamphlets he has authored.

\section{The limits of secularism in Niger}

The idea of a secularized state in Niger is unrealistic. That is the claim Muslim critics of laïcité have been making for two decades. This explains the significance of the challenges the institutionalization of secularism has faced so far in Niger. With the voices I juxtaposed, regardless their background, a consensus emerges in portraying laïcité as nothing but an institutional myth that fails to recognize the historical conditions of Niger's politics. Religious norms are too significant and Islamic agents have too much social agency to be excluded or refrain from intervention into the political arena. Most problematic is how statist discourses in Niger have circumscribed the domain of politics and decreed religion's nonintervention. In fact, as ulama argue, hukuma (political authorities) must not be dismissive of their contribution. On the contrary, ulama should be recognized as agents who "advise the ruler and serve public interest." (interview: Mai Zabura 2004) When criticism of laïcité is articulated and a framework of imperative collaboration between religious and state authorities suggested, it should not surprise that Muslims' voices diverge from and even unsettle the secularist perspective which seeks to keep religious authority at bay.

Obviously, the two parties do not share the same concept of authority. They do not share the same epistemology either. In fact, what supporters of secularism (political parties, trade unions, women's organizations, human rights organizations, etc.) criticized as an "Islamist resistance" to democratization may also be explained by the fact that Muslims rejecting secularism precisely adhere to a different epistemology. Their understanding of the state, governance and the interactions within and among these institutions differ markedly from the post-religious state, governance, and religious sphere secularists were hoping for. This alternative epistemology has not been a preoccupation for the secularist rejection of Muslim 
objections, primarily because of the assumption that Islam is inappropriate for democratic politics and will only bring intolerance and violence.

But the practice of secularism in the last few years suggests also another conclusion. The increasing use of Islamic symbols in state rituals, even though its impact needs to be better assessed, is indicative of the hope that resorting to Islamic values may strengthen political processes and state institutions. In this case, Islam is understood as the primary resource where Muslims should draw for their democratic politics as evidenced by current constitutional and administrative trends to submit authorities to a religious oath. In effect, several state institutions now require a religious oath before taking office, a provision that would have had no chance to pass in the early 1990s when discourses of laicization were at their peak. The most significant cases of religious oath include the President of the Republic, the Prime Minister, the President of the Constitutional Court, the members of the Media regulation council, the President of the Electoral Commission (Sounaye 2007), who are all required to take oath on the "book of their faith."

Other discourses I have come across during the series of fieldworks I have undertaken since 2001 contribute to wearing down the secularist citadel, especially when they insist on the fact that Muslims should enter politics as Muslims with the assumption that only true Muslim authorities can reconcile governance with the religious identity of the society. Muslims' expectations are that state officials and political leaders be Muslims so that their religiosity shapes their public office.

An interesting case in this regard is Umaru Isufu, a Christian who led in the 1990s PPNRDA (Parti Progessiste Nigérien-Rassemblement Démocratique Africain), one of the main political parties in the country. For many, Isufu's failure to mobilize and expand the party's constituency was due to his faith. I recall conversations often stressing the fact that he is not Muslim and therefore not suited to lead the party. His opponents from within as well as from outside the party would later manipulate the argument in an attempt to ruin his hopes for political leadership.

This parameter of Niger's politics is probably unjustifiable on the ground of the liberal affirmation of equality and neutrality vis-à-vis religion. But we should not forget that the determination of the law rests on an ideal type. In most cases, political and historical contingencies tell another story as individual feelings and behaviors are too often unlikely to abide by the equality-neutrality principle. Certainly, being Muslim would not guarantee success, but it represents one less hurdle for anyone aspiring to high political position. Thus, in the role religious identity plays in deciding leadership, I see a translation of a social ideology that reverberates within the political arena. If the state can affirm and seek to function on secularized principles, individual subjects in the privacy of their choice often do not, because, first, they are not required to; and second, they tend to reproduce this ideology anyway, especially in a context where Islam and Muslim organizations face the suspicion of laïcité. I am not arguing that this is specific to the democratization context, but only that it has become an issue with direct impact on the political arena when elections became the mode of devolution of power. In many regards, this difficulty is only the illustration of the limitations of the universalist doctrine of liberalization in contexts where social and political behaviors are too reluctant to espouse and celebrate the emancipated rational-legal state laïcité incarnates. That is why the political modernization project that laïcité has carried proved to be the single issue that has received systematic and consistent religious opposition. 
In any case, the struggle for Niger's government in the current context is to balance Islamic influence, mainly because of the state's foreign aid dependency and its exposure to islamizing politics. The state's personality is at stake as it has to navigate between local politics legitimizing Islam and Western aid circles and agencies unsupportive of the religionizing of political authority. These poles of constraints have affected how the state asserts its personality in the last two decades. They still affect how the government officials understand and approach the Islamic sphere.

The Muslim discourses I have presented in this article are not isolated. Rather, they represent only a sample of a politicization of Islam and of a tampering of laïcité. In general, Muslims' concern about secularism is not new in West Africa. The literature on Muslim politics in the region is replete with discussions on issues revolving around secularism, especially after the 1990's democratic struggles and the ensuing restructuring of the public sphere in many West African countries (Miles 2007; Soares and Otayek 2007; Soares 2006; Brenner 2000). In that regard, the case in Niger should be viewed in a broader context where Muslims' engagement with democratization has led to distinctive modes of assertion of religious identities never seen before. Niger's case illustrates a long tradition of concern about political authority seeking to dominate all forms of authority, including the religious. Within a context of competing moral orders, the secularization discourses of the 1990s democratization casted Islamic criticism as a threat to the materialization of human rights. Evoking shari'a (Islamic law) even in its lightest dosage was viewed as an attack against the democratic order that the framers of the constitution and secularists were seeking to consolidate. In fact, when Muslims have ventured to express alternative views on the democratization process, rebuttal has often followed along with reactions going as far as to deny them any civility (Garba 1991). As I argue elsewhere, Muslim activists have become the cause of a political neurosis in Niger, ${ }^{1}$ in part because their defiance has disturbed the moral economy secularists sought to build. Of course, this feature of Muslim politics and their representation within the public sphere is not exclusive to Niger (Gole 2006, 2002 and 2000; Soares 2006). Soares observes similar attitudes in Mali and even argues that "one of the truly striking continuities from the colonial period until the present age of neoliberalism is how Islam and Muslims are almost invariably assumed to be among the most significant potential problems for governance." (Soares 2006: 83) In the specific case of Niger, one cannot discount the role that organized Islam has assumed through various initiatives Islamic associations have undertaken, especially when the latter object that the secular norms do not do justice to the majority of Muslims who expect their political institutions to cohere with their religious identity.

In Niger, there is too much evidence of the influence of these actors on the contemporary political economy to overlook their role. In some cases, the evidence is not so much Muslims' actions, but the reactions they receive. This is often manifested through the state's regulatory intentions and exemplified by the strict separation between religion and politics as Tandja's regime has followed in its early years. This line of conduct was intended to keep in place the ideology of secularization understood as an emancipation from religious institutions and actors. A few years later however, the same regime has now opened a new phase of

1. Sounaye, "Islam, État et Société: à la recherche d'une éthique publique”, in René Otayek et Benjamin Soares, Islam, État et Société, forthcoming. 
state's regulation of Islam with the creation of an Islamic Council (Conseil Islamique) and a Ministry of Religious Affairs, the "ministry of Islam," as one of my interviewees has called it in reference to the piety of its current Minister.

\section{Concluding comments}

In order to preserve the moral personality of the state, laïcite in the early 90's meant a rejection of the influence of organized Islam. It conveyed hostility towards religion-inspired forms of intervention in the public sphere. Since then, at various occasions, Muslim clerics have raised the issue of the religious identity of Niger's politics. This has consisted in questioning the legitimacy of a state's religious neutrality when the vast majority of the Nigeriens are Muslim. Critics have seen more than neutrality, but anticlericalism and antireligiosity in laïcité.

The concern about both legitimacy and the Islamic identity of Niger's politics led to institutional reforms that made room for religious state rituals. Consequently, we should read the introduction of religion-based oath first, as a renunciation to laïcité, that is a renunciation to a strict secularism that prohibits religious determination in state institutions; and second, as the emergence of a new understanding and practice of secularism that reshape the meaning and conditions of democratization.

In discussing the conditions of possibility of an anthropological account of secularism, Asad proposes that we "start with a curiosity about the doctrine and practice of secularism regardless of where they have originated" (Asad 2003:17). This principle has guided my perspective. Obviously Asad was referring to the form of secularism that came to represent political modernity, especially within the context of the nation state. The discussion I presented here has nothing to do with the body or humanity in general, which seem to be central to Asad's problematization of secularism in the modern world. In this piece, I wanted to expose a few voices in order to illustrate the difficulty to practice secularism within Muslim and African contexts. Although the debate over secularism in Niger's democratization has focused on the doctrinal aspects, at least at the beginning of the process, for the most part, and after the constitutional consecration of the separation between religious and state authorities, the real issue became for authorities how to deal with the Islamic groups, practices and demands that were gaining increasing social support. But the case is also about the limits of $a$ secularism that seeks to radically separate religion from politics. It is safe to conclude that the hard line of laïcité has simply become impracticable in the face of growing public expectations among Muslims that their political institutions open up to their religious identity.

\section{References cited}

Alidou, Ousseina, 2005. Engaging Modernity. Madison, Wisconsin: The University of Wisconsin Press.

Alidou, Ousseina and Hassana Alidou, 2008. "Women, Religion, and the Discourses of Legal Ideology in Republic of Niger." Africa Today 54(3), p. 23-36.

An NA'IM, Abdullahi, 2008. Islam and the Secular State: Negotiating the Future of Shari'a. Cambridge, MA: Harvard University Press.

AsAD, Talal, 2003. Formations of the Secular: Christianity, Islam, Modernity. Stanford: Stanford University Press.

Brenner, Louis, 2000. Controlling Knowledge: Religion, Power, And Schooling In A West African Muslim Society. London: Hurst \& Co. 
CALhoun, Craig, 2008. <http://blogs.ssrc.org/tif/2008/03/24/recognizing-religion/> accessed June 30, 2009.

Carothers Thomas and Marina Ottanay, 2000. Funding Virtue: Civil Society Aid and Democracy Promotion. Washington, DC: Carnegie Endowment for International Peace.

Casanova, Jose, 2006. "Rethinking Secularization: a Global Comparative Perspective", The Hedgehog Review, 8 $2 \& 3)$, p. $7-22$.

Charlick, Robert B., 2004. "Islamism in West Africa: Niger", African Studies Review, 47(2), p. 97-107.

GARBA, Bello Tiousso, 1991. Interview. Haske 13.

GoLE, Nilüfer,

2000. "La laïcité, l'espace public et le défi islamiste en Turquie", Confluences Méditerranée, 33 (Printemps), p. 85-93.

2002. "Islam in Public: New Visibilities and New Imaginaries", Public Culture, 14(1), p.173-190.

2006. "Islam in European Publics: Secularism and Religious Difference", The Hedgehog Review, 8 (2\&3), p. 140-151.

Guero, Abubakr, 2004. Wa'zin Masallacin Imam Malick. Cassette-sermon, Niamey.

Hamani, Djibo, 2007. L'islam au Soudan central : histoire de l'islam au Niger du $7^{e}$ au $19^{e}$ siècle. Paris: L'Harmattan.

Hashemi, Nader, 2009. Islam, Secularism, and Liberal Democracy: Toward a Democratic Theory for Muslim Societies. Oxford and New York: Oxford University Press.

Hefner, Robert W., 2000. Civil Islam: Muslims and Democratization in Indonesia. Princeton: Princeton University Press.

HuRD, Elizabeth S, 2008. The Politics of Secularism in International Relations. Princeton, NJ: Princeton University Press.

IDRISSA, Abdouramane, 2005. "Modèle islamique et modèle occidental : le conflit des élites au Niger", in Murielle Gomez-Perez (éds.), L'islam politique au sud du Sahara, p. 347-372. Paris : Karthala.

KANE, Ousmane, 1997. "Un Pluralisme en Quête de Démocratie. Mobilisation populaire et régime militaire à Kano" in Francois Constantin and Christian Coulon (éds), Religion et transition démocratique en Afrique, p. 51-79. Paris: Karthala.

LoIMEIER, Roman, 1997. Islamic Reform and Political Change in Northern Nigeria. Evanston: Northwestern University Press.

Maikorema, Zakari, 2007. "La naissance et le développement du mouvement Izala au Niger" in Hassane Souley, Xavier Moyet et Abdourahmane Seck (éds), Islam, Sociétés et Politique en Afrique Subsaharienne: Les exemples du Sénégal, du Niger et du Nigeria, p. 51-74. Paris: Les Indes Savantes.

Masquelier, Adeline, 1999. "Debating Muslims, Disputed Practices: Struggles for the Realization of an Alternative Moral Order in Niger" in .L. Comaroff \& J. Comaroff (éds), Civil Society and the Political Imagination in Africa, p. 219-250. Chicago, University of Chicago Press.

Monga, Celestin, 1995. Anthropology of Anger: Civil Society and Democracy in Africa. London: Lynne Rienner.

Miles, William. F. S., 2007. Political Islam in West Africa: State-Society Relations Transformed. Boulder: Lynne Rienner Publishers.

OTAYек, René (éd), 1993. Le radicalisme islamique au sud du Sahara : Dawa'a, arabisation et critique de l'Occident. Paris: Karthala.

PotTer, David, 1997. "Explaining Democratization", in David Potter and others (éds), Democratization, p. 1-40. Malden, MA.: Polity Press /Open University.. 


\section{Ambiguous Secularism}

SOAREs, Benjamin F.,

2005. Islam and the Prayer Economy: History and Authority in a Malian Town. Ann Arbor: University of Michigan Press.

2006. "Islam in Mali in the Neo-Liberal Era", African Affairs, 105, p.77-95.

Soares, Benjamin. F. and René Otayek (éds), 2007. Islam and Muslim Politics in Africa. New York: Palgrave Macmillan.

Souley, Hassane, 2005. "Les nouvelles élites islamiques du Niger et du Nigeria du nord: itinéraires et prédication fondatrices", in Laurent Fourchard, André Mary et René Otayek (éds.), Entreprises religieuses transnationales en Afrique de l'Ouest, p. 350-373. Paris: Karthala.

SOUNAYE, Abdoulaye,

2005. "Les politiques de l'islam dans l'ère de la démocratisation de 1991 à 2002", in Murielle Gomez-Perez (éd.), L'islam politique au sud du Sahara, p. 503-525. Paris : Karthala.

2007. “Instrumentalizing the Qur'an in Niger Public Life”, Journal for Islamic Studies, 27, p. 211-239.

2009a. "Speaking for Islam: Ulama, Laïcité, and Democratization in Niger", American Journal of Islamic Social Sciences, 23 (Summer), p.110-127.

2009b. "Izala au Niger: une alternative de communauté religieuse", in Laurent Fourchard, Odile Goerg and Murielle Gomez-Perez (éds.), Les lieux de sociabilité urbaine dans la longue durée en Afrique, p. 481-500. Paris: L'Harmattan.

[forthcoming]. "Islam, État et Société: à la recherche d'une éthique publique au Niger", in René Otayek et Benjamin Soares (dir.), Islam, État et Société. Paris : Karthala.

Umar, Muhammad S., 1993. "From Sufism to Anti-Sufism in Nigeria", in Louis Brenner (éd.), Muslim Identity and Social Change in sub-Saharan Africa, p. 154-178. Bloomington-Indianapolis: Indiana University Press.

Villalón, Leonardo, 1996. "The Moral and the Political in African Democratization: The Code de la famille in Niger's Troubled Transition", Democratization, III (2), p. 41-68.

\section{Oral sources}

MaIgA, Adamou, 2008. Interview by author. Niamey. July.

Mai ZaBura, Mallam,

2004. Interview by author. Maradi, August.

2008. Interview by author. Maradi, July.

UMAR, Isa S., 2004. Interview by author. Niamey. August.

YAHAYA, Halidu, 2009. Interview by author. Niamey. May. 